Environ. Control in Biol. 15, 37-45, 1977

\title{
Computer Control of Plant Growth by Image Processing
}

\section{Pattern Recognition of Growth in On-line System}

\author{
Hiromi Eguchi and Tsuyoshi Matsui \\ Biotron Institute, Kyushu University, Fukuoka, Japan
}

(Received March 16, 1977)

\begin{abstract}
Present paper deals with instrumentation of image processing and statistical pattern recognition of plant growth in on-line computer system. The nine images of a cucumber plant were taken through the vidicon camera from vertical angle of $45^{\circ}$, by revolving the plants on the turn table from horizontal angle of $0^{\circ}$ to $360^{\circ}$ at an interval of $40^{\circ}$. A plant image was digitized with binary notation of $256 \times 256$ in image processor by setting a constant slice level of the brightness of the plant. The digitized image was read into CPU and stored in disk memories. The nine digitized images were summed to make a synthesized image which was expressed as the compounded matrix of Eq. (2). Clear difference in growth was observed in numerical increase and distribution of the elements of the matrix. From calculation of $\operatorname{sum}(P)$ of the elements, the quantitative growth was represented by the fuction of $P$ as given by Eq. (3). Further, in an attempt to design the classifiers for estimation of difference in feature of growth, the vertical position $(J l)$ of centroid in the compounded matrix was calculated by Eqs. (4) and (5), and relation between $l l$ and $P$ was analyzed statistically: From covariance analysis, regression equation of normal growth was different from that of succulent growth under $29-33^{\circ} \mathrm{C}$ as shown in Fig. 6 . The 95\% confidence limits of each regression equation given by Eq. (6) were used as the discriminant function. As shown in Fig. 7 , when coordinate of the point $\left(P_{i}, J l_{i}\right)$ belongs to region $\mathrm{N}$, the growth is estimated to be normal. When the point belongs to region $\mathrm{S}$, the growth is estimated to be succulent.

Thus, by image processing of plants, the growth was represented quantitatively as functions of $P$, and statistical pattern recognition in the coordinate system of $P$ and $J l$ made it possible to estimate the differences in feature of the growth.
\end{abstract}

Progress in the computer control of plant growth ${ }^{1,2)}$ is expected for establishing a new methodology of optimalizing the environments for the growth. In this field, developments of the instrumentation and the method for obtaining the informations about the growth and plant response to environments ${ }^{3)}$ are needed. For this purpose, processing of plant image is considered to be a powerful tool for non-distuctive and intact measurement of plants. ${ }^{4,5)}$ In previous paper we reported that image processing of plants taken in photographs is useful for mathematical representation of the growth. ${ }^{5)}$ Present paper deals with the instrumentation of image processing and statistical pattern recognition of the plant growth in an on-line system. 


\section{MATERIAL AND METHOD}

Material plant. Cucumber plants (Cucumis sativus L. "Ao-fushinari") were used for the experiments. Seeds were sown in chaff charcoal filled in plastic pots and germinated at $24-26^{\circ} \mathrm{C}$. From one day after gemination, plants were cultivated under respective air temperatures of $19-22^{\circ} \mathrm{C}, 24-26^{\circ} \mathrm{C}$ and $29-33^{\circ} \mathrm{C}$ and relative humidity of $60-70 \%$ in phytotron glass rooms.

Computer system for image processing and control of plant growth. The system consists of process computer (Toshiba), growth cabinet, image sensor, image decorder (PD100, Nac) and turn table, as shown in Fig. 1. The process computer is provided with CPU (Tosbac $40-\mathrm{C}, 48 \mathrm{~KB}$ ), disk memory (9.6MB), image processing interface, process interface (D-A; $10 \mathrm{ch}, \mathrm{A}-\mathrm{D} ; 2 \mathrm{ch}$ ), typewriter and photo-tape reader. The image sensor comprises vidicon camera, camera controller and monitor (television receiver). The image decoder consists of slice level controller, digitizing converter, buffer memory $(256 \times 256$ bits $)$ and timing controller. In the growth cabinet, ${ }^{6,7)}$ air temperature, air humidity and light condition (photo-period, light intensity and spectral composition) are controlled by the signals from CPU. The plant image is taken by the vidicon camera and digitized in the image decoder. The digitized image is stored in the disk memory. Process computer is used for image processing and for manipulating the environmental factors on the basis of the informations about the growth, which are obtained by the image processing.

Experimental procedure. The plants were used for image processing at an interval of 4 days during the growing period from 10 to 26 days after germination, and at the same time, their plant height, leaf area, fresh weight and dry weight were measured. The plant image was taken by the vidicon camera; the camera position was fixed at vertical angle of $45^{\circ}$, and nine images of a plant were taken by revolving the plant on the turn table from 0 to $360^{\circ}$ at an

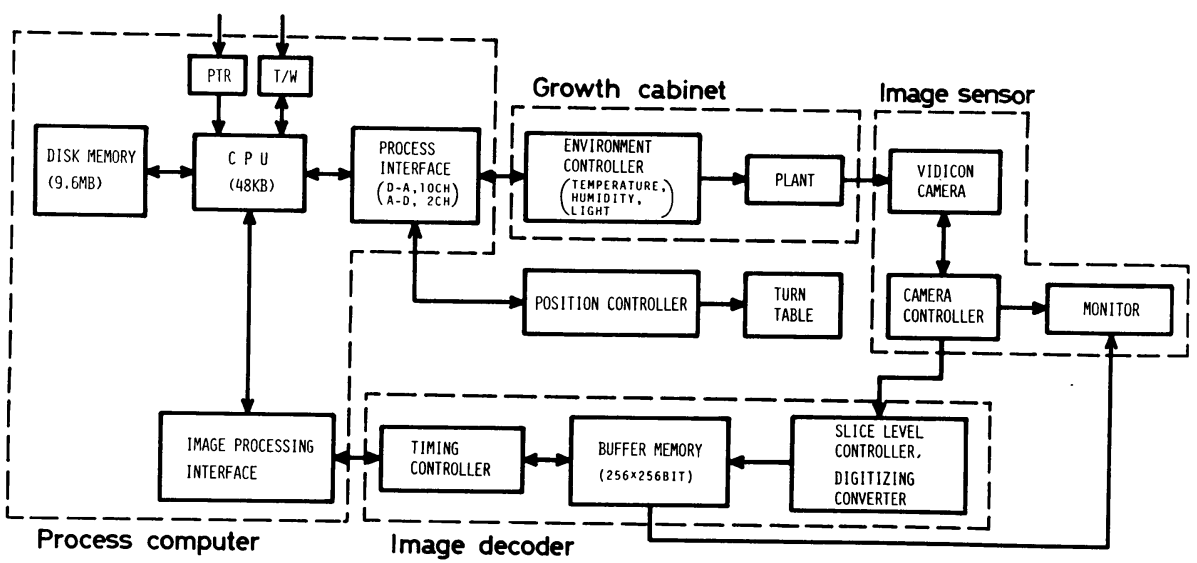

Fig. 1 Block diagram of on-line system for image processing and computer control of plant growth. 
interval of horizontal $40^{\circ}$.

In general, plants reflect large amount of long wave-length light (region of longer wave-length than $750 \mathrm{~nm}$ ). So, the artificial light (special fluorescent tubes and incandescent lamps) containing long wave-length light was used for radiation to plants, and camera sensor sensitive to long wave-length light was selected for detecting the sharp image of plants. The background of plants in the growth cabinet was painted with jetblack to eliminate noises in the image.

\section{RESULTS AND DISCUSSION}

\section{Image processing}

The plant image taken by the vidicon camera was converted into digital form by setting a constant slice level of brightness and coded in the buffer memories of $256 \times 256$ bits. The digitized image was read into the CPU through the interface and stored in the disk memories. Figure 2 shows the digitized image of a plant in a matrix of binary notation and photographs of the plant image in the monitor. Photograph (a) is the image with normal gradient of brightness, and photograph (b) is the digitized image of binary notation obtained by setting a slice level of brightness, in which ' 0 ' is black and ' 1 ' is white. Thus, a slice level was selected as to denote an overall gradient of brightness of the plant as
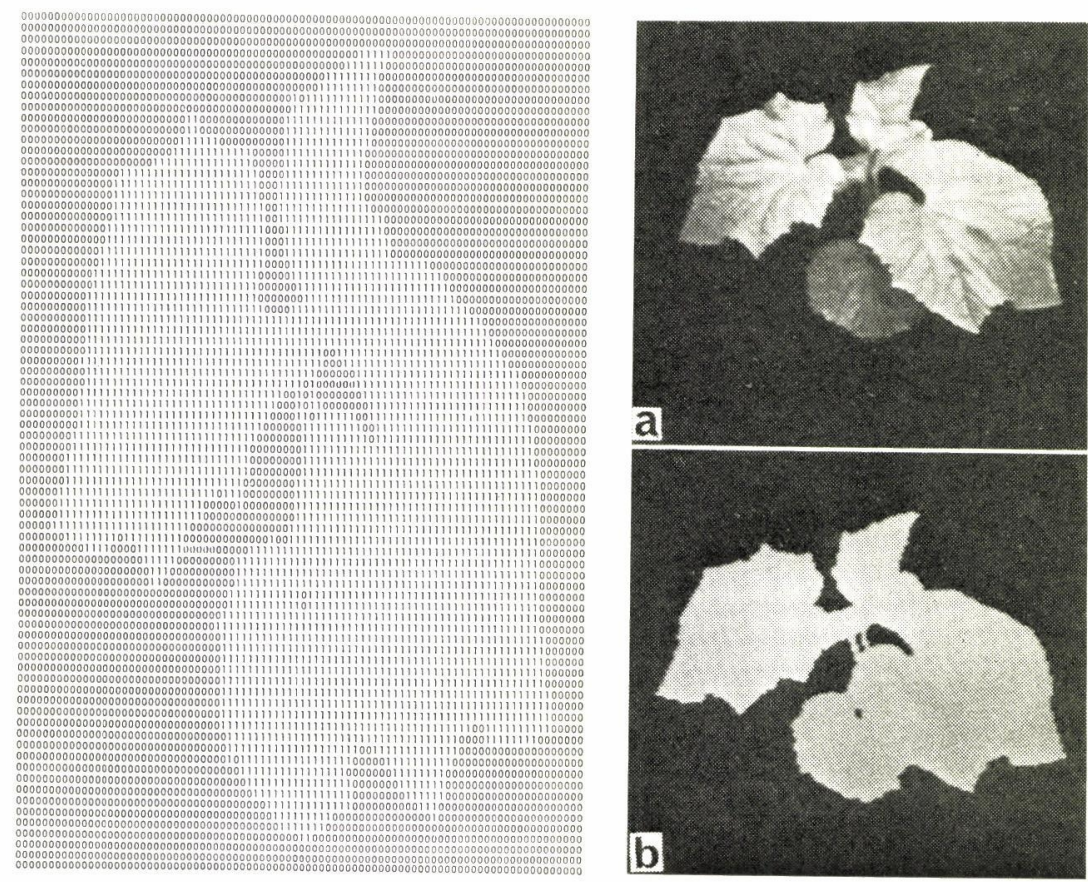

Fig. 2 Matrix of a digitized plant image expressed by binary notation and photographs with natural gradient (a) and with digitized image (b) obtained by setting a constant slice level of brightness of the plant. (Odd numbers of row and column were omitted) 
' 1 ' and denote background as ' 0 .' The shapes of plant images taken from different angles appear in various forms, owing to the phyllotaxis and other factors. As was reported in previous paper, ${ }^{5)}$ it is known that the aspect of the growth can be detected well by summing the plant images taken from different angles in order to eliminate the change and the deviation of the plant shapes. In this study, nine plant images which were taken at an interval of horizontal $40^{\circ}$ were summed in the disk memories to make the synthesized image expressed by a compounded matrix. Figure 3 shows compounded matrixes of the images of 14 days old plant (a) and 18 days old plant (b) grown under air temperature of 24$26^{\circ} \mathrm{C}$. Each of the numerical elements means the summing round in the synthesis of the image. The shape of synthesized image of a plant in the compounded matrix appeared to be an ellipse. During 4 days of growing period from 14 days to 18 days, clear difference was observed in enlargement of the ellipse and also in numerical increase of the elements in the compounded matrix.

\section{Mathematical representation of plant growth}

Thus, the plant growth was clear in quantitative change of synthesized image of a plant in compounded matrix. For the purpose of numerical estimation of the growth, sum $(P)$ of elements of the compounded matrix $(M c)$ were calculated, that is

$$
P=\sum_{j=1}^{n} \sum_{i=1}^{m} a_{j i}
$$

where $a_{j i}$ is an element of the matrix and its arrangement is expressed as follow,

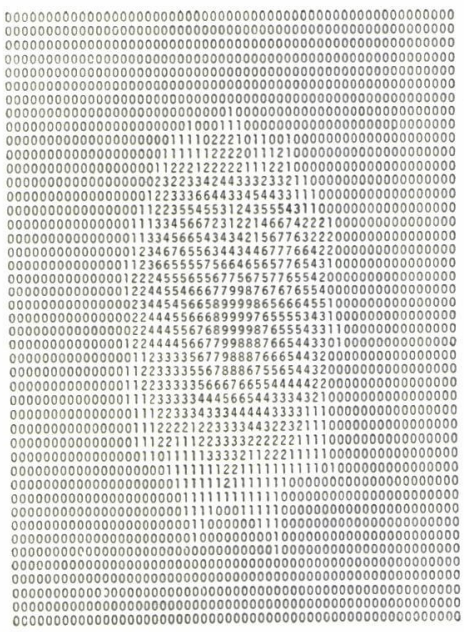

(a)

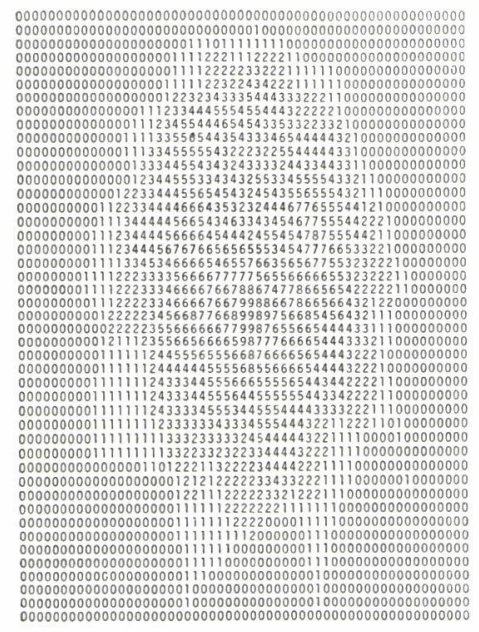

(b)

Fig. 3 Parts of the compounded matrixes obtained by summing the nine images of 14 days old plants (a) and of 18 days old plant (b).

(Odd numbers of row and column were omitted) 


$$
M c=\left[\begin{array}{ccccc}
a_{11} & \cdots & a_{1 i} & \cdots & a_{1 m} \\
\vdots & & \vdots & & \vdots \\
a_{j 1} & \cdots & a_{j i} & \cdots & a_{j m} \\
\vdots & & \vdots & & \vdots \\
a_{n 1} & \cdots & a_{n i} & \cdots & a_{n m}
\end{array}\right], \quad m, n=256
$$

Relation between the growth and $P$ is shown in Figs. 4 (a)-(d). Respective regression equations of plant height $(P h, \mathrm{~cm})$, leaf area $\left(L a, \mathrm{~cm}^{2}\right)$, fresh weight $(F w, \mathrm{~g})$ and dry weight $(D w, \mathrm{~g})$ on $P$ were given by

$$
\begin{aligned}
& P h=4.95 \times 10^{-9} P^{2}+4.35 \times 10^{-4} P+4.25 \\
& L a=1.86 \times 10^{-2} P-16.8 \\
& F w=2.65 \times 10^{-9} P^{2}+6.07 \times 10^{-4} P-0.65 \\
& D w=6.19 \times 10^{-5} P-9.92 \times 10^{-2}
\end{aligned}
$$

Thus, the plant growth even under different temperatures were represented quantitatively by the function of $P$.
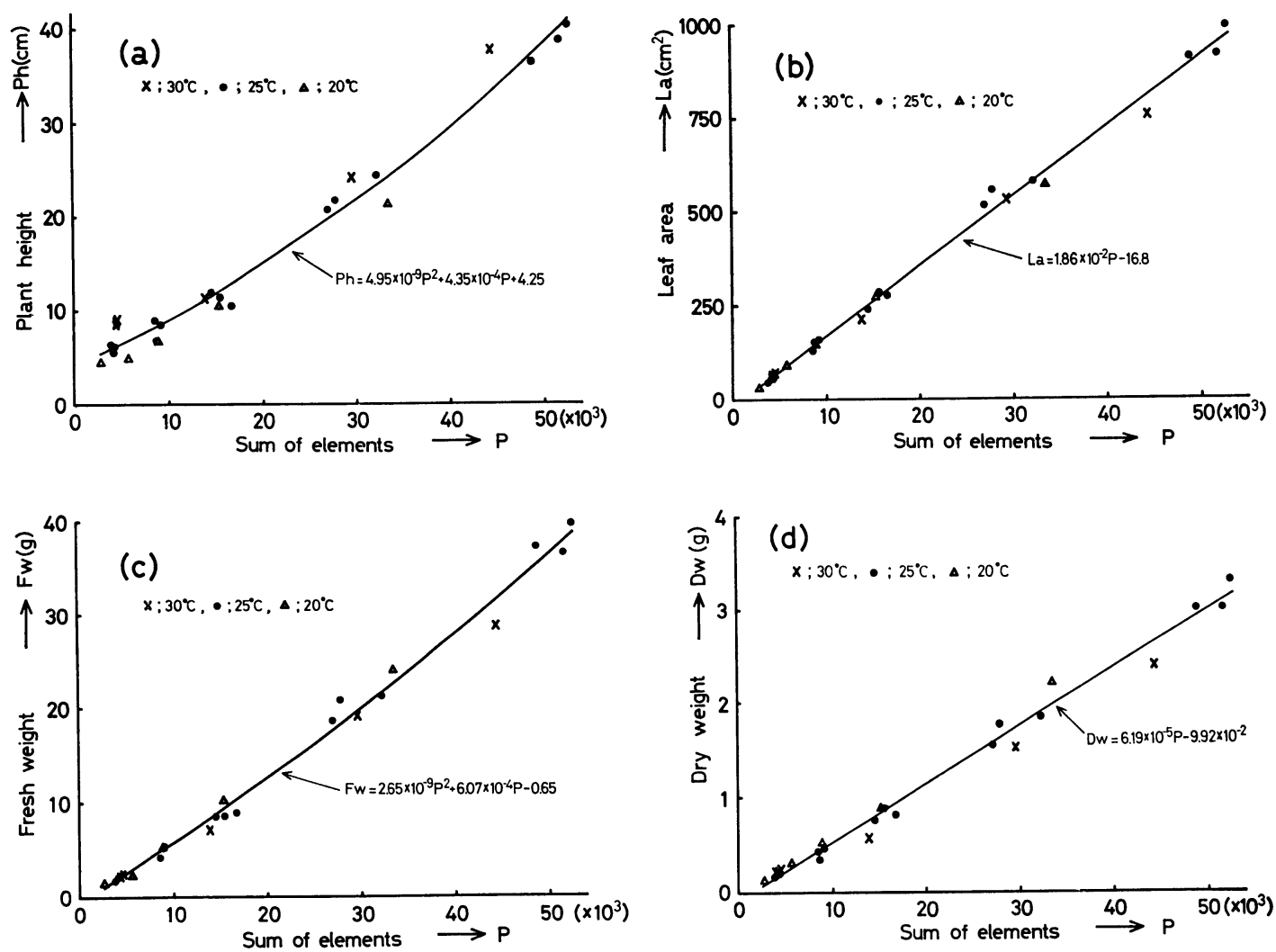

Fig. 4 Relations between sum of elements of the compounded matrix and the growth of plant height (a), leaf area (b), fresh weight (c) and dry weight (d) under different temperatures. 


\section{Classifier design for estimation of difference in feature of growth}

The plant growth under different environments appears in different features, and the feature of the growth could be classified to several types. The succulent growth is a type of the abnormal growth which occurs frequently under higher temperatures with special combinations of air humidity, light condition and nutrients. In this experiment, the succulent growth was observed in the plants grown under air temperature of $29-33^{\circ} \mathrm{C}$ and was used as a typical reference to estimation of difference in feature of the growth. The difference in feature of the growth could not be estimated from Eq. (1). So that, it was attempted to design the classifiers for estimation of difference between normal growth and abnormal growth. On the compounded matrix, the difference in feature of the growth was observed in changes of numerical distribution of elements. In the succulent growth under higher temperatures, numerical increase of the elements distributed relatively at the upper part of the compounded matrix. So, in an attempt to estimate the difference in the distribution of elements, vertical position (Ju) of the centroid of the image from upper datum in the compounded matrix was calculated as shown in Fig. 5, that is

$$
J u=\sum_{j=1}^{n}\left(j \cdot \sum_{i=1}^{m} a_{j i}\right) / \sum_{j=1}^{n} \sum_{i=1}^{m} a_{j i}
$$

As a matter of course, $J u$ moved from the lower part to upper part according to the growth. So, $J u$ was converted into

$$
J l=256-J u
$$

for observing the movement of the centroid from the lower datum. Thus, $J l$ was calculated from the image processing as well as $P$. As mentioned before, the difference in feature of the growth could not be estimated by the function of $P$. So, in order to estimate feature of growth, the relation between $P$ and $J l$ was

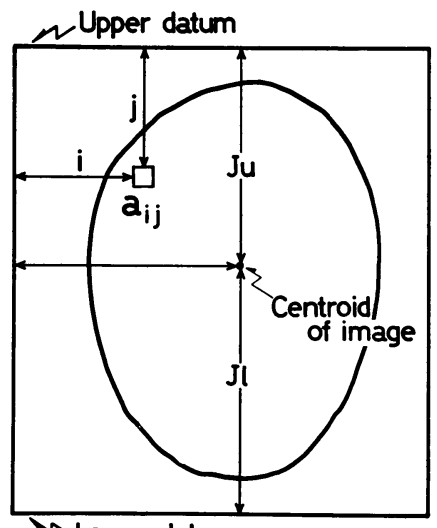

Lower datum

Fig. 5 Expression of centroid in the compounded matrix.

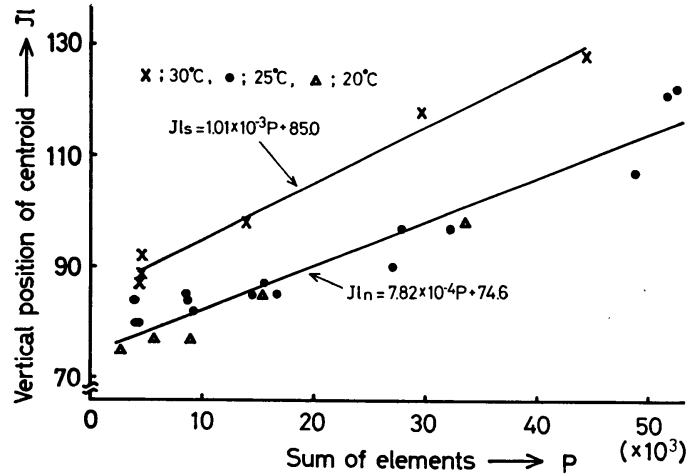

Fig. 6 Relation between sum $(P)$ of elements and vertical position $(J l)$ of centroid in the compounded matrix of the image of plants grown under different temperatures. 
analyzed statistically with the use of plants grown under different temperatures. Figure 6 shows the relation between $P$ and $J l$ in the different types of growth. In $P$ and $J l$ coordinate system, there was appreciable difference between normal growth and succulent growth in their distributions. That is, the relation between $P$ and $J l$ in normal growth under $19-22^{\circ} \mathrm{C}$ and $24-26^{\circ} \mathrm{C}$ was different from that in succulent growth under $29-33^{\circ} \mathrm{C}$. The respective regression equations of $J l$ in normal growth $(J l n)$ and succulent growth $(J l s)$ on $P$ were given by

$$
\left.\begin{array}{l}
J l n=7.82 \times 10^{-4} P+74.6 \\
J l s=1.01 \times 10^{-3} P+85.0
\end{array}\right\}
$$

From the covariance analysis, ${ }^{8)}$ it was demonstrated that the difference between the regression equation of normal growth and that of abnormal growth is significant at $5 \%$ level. The $95 \%$ confidence limits of $J l n$ and $J l s$ on $P$ were given by

$$
\left.\begin{array}{l}
C l n_{1,2}=J l n \pm 8.11 \times\left(1.93 \times 10^{-10} P^{2}-7.55 \times 10^{-6} P+1.12\right)^{1 / 2} \\
C l s_{1,2}=J l s \pm 7.04 \times\left(7.17 \times 10^{-10} P^{2}-2.42 \times 10^{-5} P+1.37\right)^{1 / 2}
\end{array}\right\}
$$

where $C \ln _{1,2}$ and $C l s_{1,2}$ are upper and lower confidence limits of $J l n$ and $J l s$ at given $P$, respectively. Thus, 95\% confidence intervals around $J l n$ and $J l s$ distribute within respective ranges between $C \ln _{1}$ and $C \ln _{2}$, and between $\mathrm{Cls}_{1}$ and $\mathrm{Cls}_{2}$, as shown by oblique lines in Fig. 7. For the classifier design ${ }^{9,10)}$ to estimate the difference in feature of growth, the confidence limits are considered to be usable as the discriminant function. ${ }^{11}$ The confidence limits of $C \ln _{1}$ and $\mathrm{Cls}_{2}$ crossed each other at $P=24845$, and confidence interval between $C \ln _{1}$ and $\mathrm{Cln}_{2}$ was superimposed on that between $C l s_{1}$ and $C l s_{2}$ when $P<24845$. On the basis of the confidence intervals, the region of normal growth (N) was denoted by

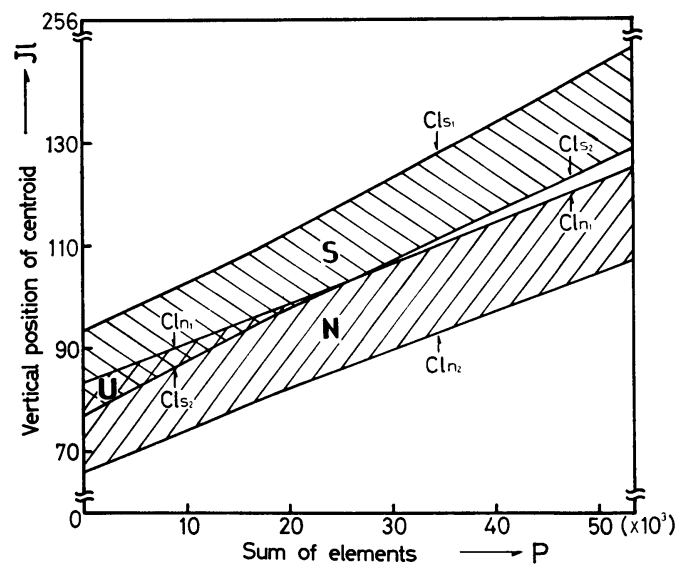

Fig. 7 Regions of different types of growth, classified by using the confidence limit as the discriminant function in the coordinate system of $P$ and $J l$.

$$
\left.\begin{array}{rr}
C l n_{2} \leqq J l<C l s_{2}, & 0<P \leqq 24845 \\
C l n_{2} \leqq J l \leqq C l n_{1}, & 24845<P<52000
\end{array}\right\}
$$

That is, when coordinate of the point $\left(P_{i}, J l_{i}\right)$ belongs to $\mathrm{N}$, the growth is estimated to be normal.

The region of succulent growth $(\mathrm{S})$ was denoted by

$$
\left.\begin{array}{lr}
C l n_{1}<J l \leqq C l s_{1}, & 0<P \leqq 24845 \\
C l s_{2} \leqq J l \leqq C l s_{1}, & 24845<P<52000
\end{array}\right\}
$$




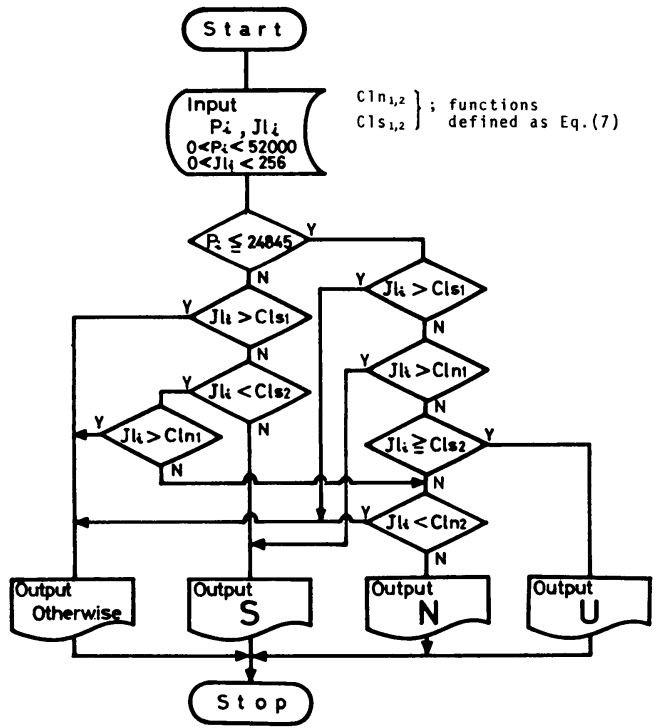

Fig. 8 A flow chart for classification of features of the growth.
That is, when coordinate of the point $\left(P_{i}, J l_{i}\right)$ belongs to $\mathrm{S}$, the growth is estimated to be succulent.

The region (U) where two confidence intervals were superimposed on each other, was denoted by

$$
C l s_{2} \leqq J l \leqq C l n_{1}, \quad 0<P \leqq 24845
$$

That is, when the point $\left(P_{i}, J l_{i}\right)$ belongs to $U$, the growth cannot be estimated to be normal or succulent.

Otherwise, when the point $\left(P_{i}, J l_{i}\right)$ does not belong to any regions of $\mathrm{N}$, $\mathrm{S}$ and $\mathrm{U}$, the growth is estimated at least not to be normal.

A flow chart for classification of features of plant growth is shown in Fig. 8. Thus, the plant growth was represented quantitatively by $\operatorname{sum}(P)$ of the elements of compounded ma-

trix, and difference in feature of the growth was estimated by statistical pattern recognition in the coordinate system of $P$ and $J l$ which is vertical position of centroid of the synthesized image in the compounded matrix. By this method of image processing of plants, the evaluations of the growth were made possible for manipulation of environmental factors.

\section{REFERENCES}

1) Matsui, T., and H. EgUChi. 1972. Regulation of plant growth and differentiation by automatic program control of environmental factors with the use of computer. I. Regulation of hypocotyl elongation of cucumber by automatic program control of temperature. Environ. Control in Biol. 10 (1): 23.

2) Takakura, T., T. KozaI, K. Tachibana, and K. A. Jordan. 1974. Direct digital control of plant growth. I. Design and operation of the system. Transactions of the ASAE $17(6): 1150$.

3) Hashimoto, Y., A. Fukuya, F. Aвo, and S. Funada. 1976. Process identification and optimal control of plant growth. (II) Relationship between dynamic characteristics of water content and physiological informations in plants as affected by step input of environmental elements. Environ. Control in Biol. 14 (3): 59 (in Japanese with English summary).

4) TAмAKI, K., and J. DoI. 1974. Pattern instrumentation. (2) Computer control with data acquisition and instrumentation. Journal of the Society of Agricultural Machinery, Japan 35 (1): 102 (in Japanese with English summary).

5) Matsui, T., and H. EGUCHI. 1976. Computer control of plant growth by image processing. I. Mathematical representation of relation between growth and pattern area taken in photographs of plants. Environ. Control in Biol. 14 (1): 1.

6) Matsui, T., H. Eguchi, Y. Hanami, S. Hanada, and T. Terajima. 1971. A growth cabinet for the study on biotronics. I. Design and performance. Environ. Control in 
Biol. $9(1,2): 37$.

7) Matsui. T., H. Eguchi, and Y. Soejima. 1975. Control of artificial light for plants. II. Automatic control of light intensity and spectral composition. Environ. Control in Biol. 13 (3): 109.

8) Snedecor, G. W., and W. G. Cochran. 1967. Statistical methods (6th edition). The Iowa State University Press, Ames.

9) Ahmed, N., and K. R. RAo. 1975. Orthogonal transforms for digital signal processing (Chapt. 10, Feature selection in pattern recognition). Springer-Verlag, Berlin, Heidelberg, New York.

10) FU, K. S. (ed). 1976. Digital pattern recognition. Springer-Verlag, Berlin, Heidelberg, New York.

11) FUKUNAGA, K. 1972. Introduction to statistical pattern recognition. Academic Press, New York and London.

\title{
<和文抄録 $>$
}

\section{画像処理による植物生育の電算機制御}

\section{II. オンラインシステムにおける生育のパターン認識}

\author{
江口弘美・松 井 健 \\ 九州大学生物環境調節研究センター
}

前報で，植物生育の電算機制御に必要な生育情㪕を得る 1 つの方法として，植物の幽像処埋が有効で あることが明らかとなった。本韩では，テレビカメラと電算機を用いたオンラインシステムによって植 物の画像処理をおこない，統計的パターン認䜟による生育評価法の確立を試みた。

材料植物としてはキュウリ“背節成”を用い，フォイトトロンガラス室内で $19 \sim 22^{\circ} \mathrm{C}, 24 \sim 26^{\circ} \mathrm{C}$, $29 \sim 33^{\circ} \mathrm{C}$ (相刘湿度 $60 \sim 70 \%$ ) の各温度条件下で栽培した. 発芽後 10 26 日間に，4 日ごとに画像処 理と生育测定をおこなった。

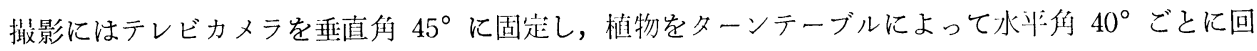
転して9 個の画像を撮った。各画像を, 植物の全像だけが‘ 1 ’をなる反射輝度のスライスレベルを設走 して，256×256 メッシュで 2 值化し，ディスクメモリに記怕した。これら 9 個の 2 值化画像を㞦算し て，合成マトリックスを得た，合成マトリックスに拈ける植物像は棈円状となり，生育にしたがって楕 円の大きさと合成マトリックスの要素の数的增加が贸められた．この合成マトリックスの荘素の和 $(P)$

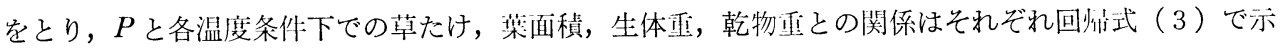
され，生育の量的評体が可能となった。一方，高温条件下 $\left(29 \sim 33^{\circ} \mathrm{C}\right)$ での生青は徒長状態となるが, $P$ によっては正常な生育との樴别が不可能であった。とこで, 合成マトリックスにおける眓心 (centroid)

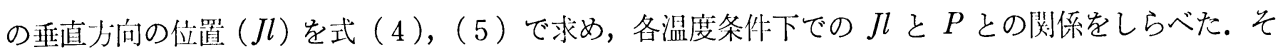
の絬果，正常な生育と徒長とは 2 つ群に分かれ，それぞれ異なる回㸉式を有することが明らかとなっ た，正常生育と徒長との分類をおこなうための識別関数として，それぞれの回州式の信頼限界式 (8) を用い，生育特性のクラス分類法をつくった。この方法では，たとえば Fig. 7,8 において点 $\left(P_{i}, J l_{i}\right)$ が $\mathrm{N}$ に含まれるならば正常，S に含まれるならば徒長と識別される。したがって, 植物画像処理で得 られた $P$ および $J l$ を用いて,生育の量的評価と同時に生育特性の差異を識別することが可能となった. 